\title{
How does the virus spread?
}

\author{
Samuel R. Friedman
}

Published online: 27 March 2010

(C) Springer Science+Business Media B.V. 2010

While the poor in America

continue to sicken, continue to die, memories of funerals outpace

memories of births

in structurally adjusted Africa.

While viruses invade the poor

of India, Nigeria, Vietnam,

China and Indonesia,

virus skulks hunted in healthy bodies

in the countries that once ruled the South,

in the countries whose banks and manufacturers

cherry-pick desperate lands for factories, loans, or

foreclosures,

seek their lifeblood profits

in the labors and veins of the poor.

The needs of investors and Presidents

draw red ink and black ink

from the wealth of our bloodstreams,

scribble "life" here,

"death" there,

profits here, losses there, debts most everywhere, write cutbacks, write wars.

They stifle the joys of transitions, those festivals of the oppressed, with structural adjustments and good governance, pretending to nurture healthy futures through healthy business, healthy lives through breaking hopes.

This is the way the virus spreads, this is the way the virus spreads, this is the way the virus spreads, not only behavior but their whimpering need for profits, evermore profits, evermore, until we end it. 